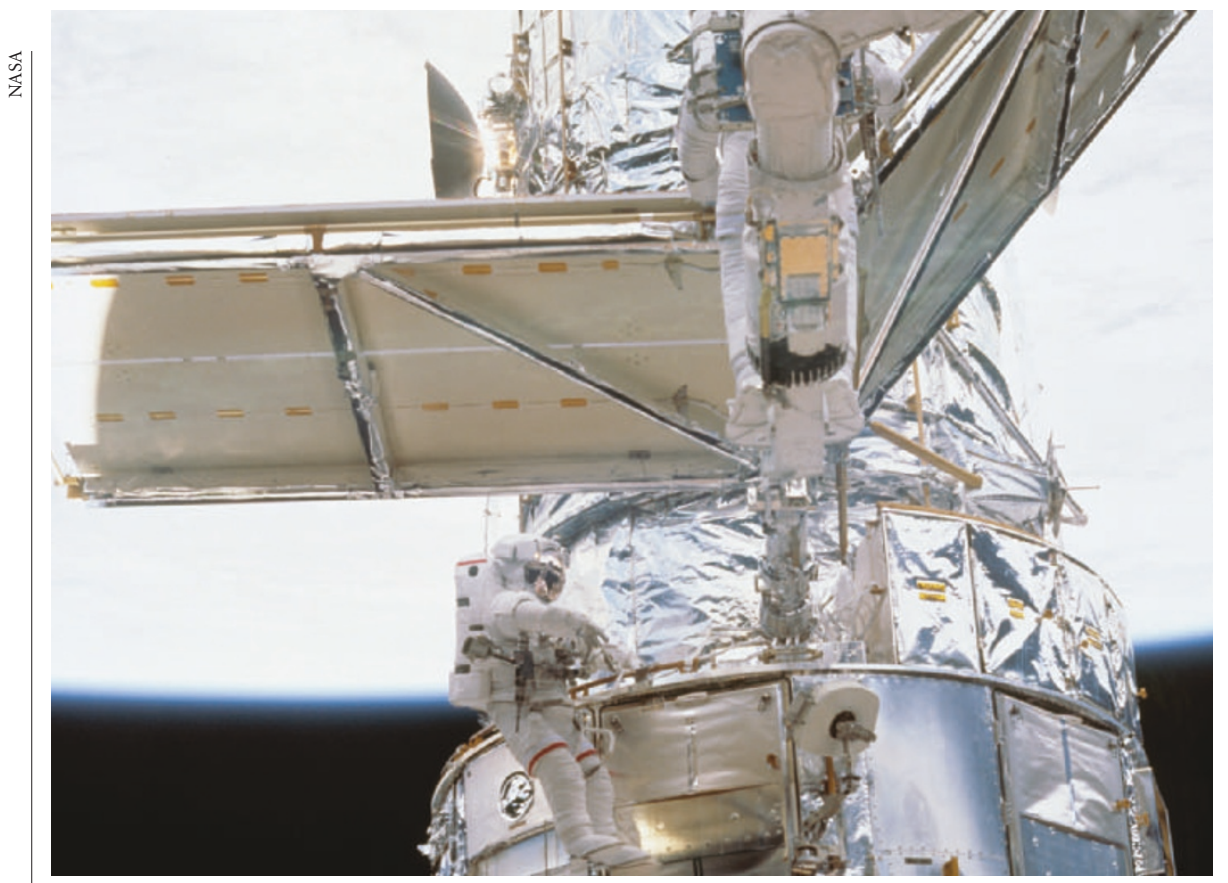

Back in the picture: astronauts could once more be sent to service the Hubble Space Telescope.

\title{
NASA boss takes the helm and launches plans for the future
}

Tony Reichhardt, Washington

NASA's new administrator, Michael Griffin, got off to a flying start last week before he had even been sworn in. At his Senate confirmation hearing on 12 April, he reopened the possibility of sending astronauts to service the Hubble Space Telescope, an option his predecessor Sean O'Keefe ruled out last year (see Nature 427, 273; 2004).

The next day, the Senate approved Griffin as the space agency's 11th - and perhaps most technically savvy - leader. Members of Congress had nothing but praise for the 55year-old engineer and physicist, who arrives at NASA at what he calls a "watershed moment", as the United States tries to reinvigorate human spaceflight with an ambitious plan to send astronauts beyond Earth orbit for the first time in decades.

Griffin wholeheartedly supports that goal, and he's impatient to get started. NASA had planned to have a new Crew Exploration Vehicle ready for outbound astronauts by 2014, but Griffin told senators that he hopes to speed up the pace of development. "People want a space programme that goes somewhere and does something," he told NASA employees on 14 April.

First, though, he'll focus on getting the shuttle flying again - before retiring it as soon as the International Space Station is completed "in a manner consistent with our international partner commitments”.

O'Keefe's decision to scrap the idea of sending a shuttle to service the ageing Hubble telescope was made in the immediate aftermath of the doomed Columbia shuttle mission, Griffin said, adding that he wants to revisit the plan once the shuttle has successfully flown again - a mission planned for late next month (see Nature 434, 811;2004).

Griffin also called for a balanced programme of science, astronaut exploration and aeronautics. He claimed that NASA can afford them all, pointing out that the agency's current budget is equivalent to that at the time of the Apollo Moon missions in the 1960 s and 1970s.

$\mathrm{He}$ also defended NASA's science programme, calling it "one of our crown jewels". "I don't agree that it has fallen by the wayside," he added, but admitted that he could understand why scientists are worried. Spending on the new Moon-Mars programme and the shuttle's return to flight "has caused temporary dislocations in science funding", he said, that are likely to continue for the time being.

In his exchanges with senators and NASA employees, Griffin was as direct as his predecessor had been discursive, showing how he earned himself a reputation as a straight talker.

Before the congressional committee, he referred to himself as "a simple aerospace engineer from a small town”. Standing before his new employees, he stressed humility and collegiality. "I'm not sir, I'm not Dr Griffin. I'm Mike or Michael," he said before the packed auditorium at the agency's Washington headquarters. "The NASA administrator is not royalty."

\section{Scientists speak out in search of fame and fortune}

Jim Giles, London

Three minutes, no slides and immediate, hard-hitting feedback from a panel of judges: tough conditions for even the most seasoned of orators. But for the past few weeks, hundreds of UK scientists have been subjecting themselves to this ordeal in a bid to win the sciencecommunication competition FameLab.

The regional heat in London on 14 April saw contestants wax lyrical about everything from the science behind the "perfect design of the penis" to the difficulty of defining what is and isn't a drug. Each then faced the enthusiastic but occasionally blunt thoughts of the judging panel, while their audience watched.

Many entrants say that they see FameLab as a way of developing outreach skills. "Science communication will be a big part of my career," says Ed Moran, who is studying for a $\mathrm{PhD}$ in infectious diseases at the University of Oxford. His talk involved a bedpan containing chocolate spread, and discussed how human faeces could be used to replenish gut bacteria.

But it was Matt Wilkinson, a zoologist at the University of Cambridge, and Rebecca Lloyd-Evans, a biotechnology consultant with Cambridge-based firm BioBridge, who impressed the six judges enough to secure places in the 12-strong final, to be held in June at the Cheltenham Festival of Science. The pair triumphed with respective talks on animal locomotion and the link between manic depression and creativity.

The overall winner will get $\mathfrak{E} 2,000$ (US\$3,800), a part in a TV science programme on Britain's Channel 4 and a speaking tour. The competition, organized by the Cheltenham festival and the UK National Endowment for Science, Technology and the Arts, was inspired by the hit TV show Pop Idol, in which aspiring pop stars audition before a celebrity panel.

The judges say that the quality of entries has been high. "I've been really impressed," says Kathy Sykes, who holds a chair in science communication at the University of Bristol. She notes that scientists often have more passion for their subject than professional communicators - and that passion and enthusiasm, rather than a polished performance, were priorities for the judges.

"Everyone has been really good," adds science author and judge Simon Singh. "We haven't had the Pop Idol thing where people just can't sing."

www.famelab.org 